This document is the Accepted Manuscript version of a Published Work that appeared in final form in Dyes

and Pigments 126 (2016) 147e153 http://dx.doi.org/10.1016/j.dyepig.2015.11.002

\title{
Charge recombination losses in thiophene-substituted porphyrin dye-sensitized solar cells
}

\author{
Susana Arrechea ${ }^{a}$, John N. Clifford ${ }_{*}^{b}$, Laia Pelleja ${ }^{b}$, Ana Aljarilla ${ }^{a}$, Pilar de la Cruz ${ }^{a}$, Emilio \\ Palomares ${ }^{\text {b c }{ }^{* *} \text {, Fernando Langa }}$, \\ ${ }^{\mathrm{a}}$ Universidad de Castilla-La Mancha, Instituto de Nanociencia, Nanotecnología y Materiales Moleculares (INAMOL), 45071, Toledo, Spain \\ ${ }^{\mathrm{b}}$ Institute of Chemical Research of Catalonia (ICIQ), Avda. Països Catalans, 14, Tarragona, E-43007, Spain \\ ${ }^{c}$ ICREA, Passeig Lluis Companys, 23, Barcelona, E-08010, Spain
}

\begin{abstract}
a b s tract
Two new porphyrins that incorporate thiophene substituents as spacers between the conjugated porphyrin core and the anchoring cyanoacrylate group have been synthesised. The two dyes differ in the number of thiophene bridges; porphyrin 1a has only one thiophene group and porphyrin $1 \mathrm{~b}$ has two thiophene rings connected by a double bond. The measured light-toenergy conversion efficiencies in 1a and $1 \mathrm{~b}$ were assessed using two different electrolytes, LP1 and LP2, which differ in the presence of tert-butyl pyridine in LP1. An efficiency of $6 \%$ under standard measurement conditions has been achieved for 1 a p LP1. However, for porphyrin $1 \mathrm{~b}$ the use of electrolyte LP1 led to lower efficiencies and a value of approximately $4 \%$ was obtained. The differences between the two types of solar cells and the electrolytes have been studied in-depth using photoinduced time-resolved techniques such as CE (Charge Extrac-tion) and TPV (Transient PhotoVoltage).
\end{abstract}

\section{Introduction}

Mesoporous $\mathrm{TiO}_{2}$ dye-sensitized photo-electrochemical solar cells, also known as Gratzel€ solar cells, have achieved efficiencies as high as $12 \%$ under sun-simulated conditions [1]. Recently, the first application of Building Integrated Photo-Voltaic technology (BIPV) was demonstrated and this showed the potential of a colourful and transparent solar cell technology [2]. In this type of solar cell the properties of the dye, such as colour, molecular extinction coeffi-cient and robustness under illumination, are of utmost importance. Among the examples of dyes published in the literature [3] for Gratzel€ solar cells, porphyrins [4] have pleasant colours [5], excel-lent molecular extinction coefficients $[6,7]$ and good robustness $[8,9]$. Moreover, based on the work of Yella and co-workers [1], efficiencies that surpass the values obtained with ruthenium sen-sitizers have been achieved. However, these remarkable

\footnotetext{
* Corresponding author.

** Corresponding author. Institute of Chemical Research of Catalonia (ICIQ), The Barcelona Institute of Science and Technology, Avda. Països Catalans, 14, Tarragona, E-43007, Spain.

E-mail address: Fernando.Langa@uclm.es (F. Langa).
}

asymmetric porphyrins, which are based on DepeA molecular structures (Donor-p-Acceptor), are difficult to synthesise and scale up to kilogram quantities and this represents a major drawback for their use in solar modules for BIPV.

Several groups, including our own, have proposed other types of porphyrins [10e14] that are easier to synthesise and purify and show efficiencies of around $5 \mathrm{e} 7 \%$ under sun-simulated light irra-diation conditions [15e20].

In the work described here we synthesised two novel Zn-porphyrin-based structures (Fig. 1) that contain thiophene moi-eties as spacers between the $\mathrm{Zn}$ porphyrin and the anchoring cyanoacrylic acid. The electronic properties of the compounds were studied and they were also evaluated as components in solar cells. The novel $\mathrm{A}_{3} \mathrm{~B} \mathrm{Zn}$-porphyrins are tri-substituted with triphenylamine groups (TPA) as secondary electron donors (D); the volume of the TPA groups also helps to diminish the natural tendency of porphyrins to aggregate, which in turn diminishes the antenna effect of the porphyrins.

The efficiencies of the solar cells in two different electrolytes are discussed and compared in terms of charge density, as measured by the charge extraction technique, and device recombination kinetics under working conditions, as measured using the photo-induced transient photovoltage. The aim of the study was to demonstrate 


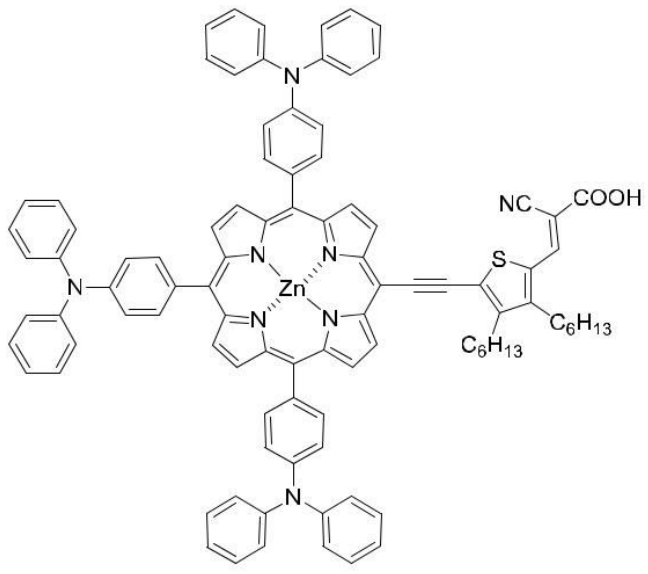

$1 \mathrm{a}$

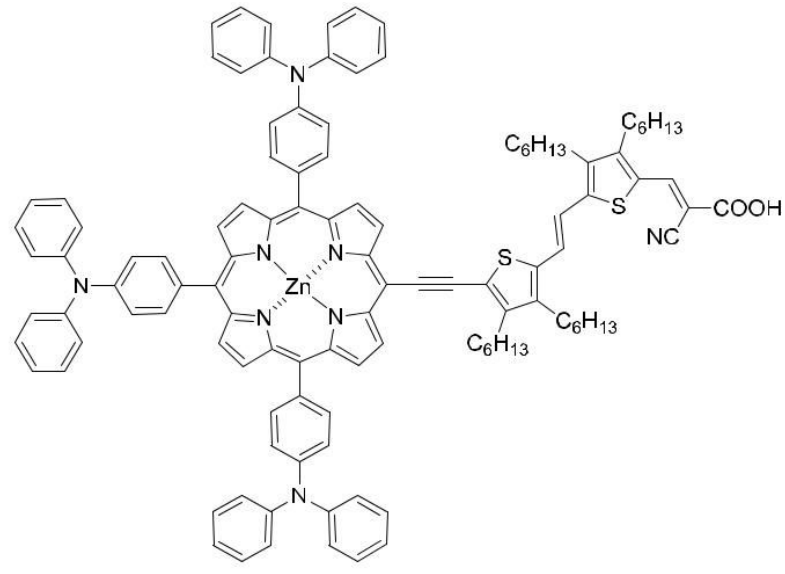

1b

Fig. 1. Structures of dyes $1 \mathrm{a}$ and $1 \mathrm{~b}$

that the electrolyte interaction with the dye plays a critical role and this could have a different effect on two porphyrins that differ only in the length of the conjugated thiophene-based system used in the $\mathrm{p}$-conjugated molecular bridge.

\section{Results and discussion}

The synthesis of dyes $1 a, b$ was performed starting from trimethylsilylporphyrin 2 (Scheme 1) [10,21]. Firstly, the trimethylsilyl group was quantitatively removed by reaction with TBAF and this was followed by copper-free Pd-catalysed Sonogashira coupling [22] with 2-iodothiophene derivatives 3aeb $[23,24]$ Under these conditions, the reaction proceeded smoothly to afford aldehydes $4 \mathrm{a}, \mathrm{b}$ in $83 \%$ and $80 \%$ yield, respectively. Subsequent Knoevenagel condensation of $4 a, b$ with cyanoacetic acid, using piperidine as base, yielded $1 \mathrm{a}, \mathrm{b}$ in $89 \%$ and $82 \%$ yields, respectively, after purifi-cation by column chromatography (silica gel, chloroform: methanol 10:1). All new compounds were fully characterised by FT-IR, ${ }^{1} \mathrm{H}$ and ${ }^{13} \mathrm{C}$ NMR spectroscopies and by MALDI-TOF mass spectrometry (see experimental section and ESI). It should be noted that in $4 \mathrm{~b}$ and $1 \mathrm{~b}$ the trans character of the double bond was confirmed by the coupling constant of around $15 \mathrm{~Hz}$ between the two vinyl protons in the ${ }^{1} \mathrm{H}$ NMR spectra. Compounds $1 \mathrm{a}, \mathrm{b}$ were reasonably soluble in several common organic solvents, such as $\mathrm{CH}_{2} \mathrm{Cl}_{2}, \mathrm{CHCl}_{3}$ and THF, and this allowed the preparation of DSSCs. The thermal stabilities of compounds $1 \mathrm{a}, \mathrm{b}$ were evaluated by thermogravimetric analysis (TGA) under nitrogen, with a heating rate of $10 \mathrm{C} / \mathrm{min}$. The decomposition temperatures (Td) were estimated from the TGA plots as the temperature of the intercept of the leading edge of the weight loss curve. Under these conditions, compounds $1 \mathrm{a}$ and $1 \mathrm{~b}$ display excellent thermal stability up to $200 \mathrm{C}$ (Figs S17 and S18, ESI) and this makes them suitable for application in photovoltaic devices.

\subsection{Optical properties}

The optical properties of $1 a, b$ were studied by UV-Visible spectrophotometry in solution and both compounds exhibited a panchromatic absorption in the visible region. A solution of $1 \mathrm{a}$ in THF exhibited the characteristic absorption pattern of a $\mathrm{Zn}$-chelated porphyrin, with an intense Soret band (B band) at $471 \mathrm{~nm}(\log \varepsilon 1 / 44.99)$ and an intense intermolecular charge transfer (ICT) band at $662 \mathrm{~nm}(\log \varepsilon 1 / 44.53)$; between these bands, one of the $\mathrm{Q}$ bands was observed at $583 \mathrm{~nm}(\log \varepsilon 1 / 43.93)$. Extension of the conjugation on the bridge by the introduction of a new thienyle-nevinylene unit had a significant effect on the absorption spectrum of $1 \mathrm{~b}$, leading to a panchromatic absorption as the Soret band was red-shifted to $460 \mathrm{~nm}(\log \varepsilon 1 / 4$ 5.21) and a new absorption band

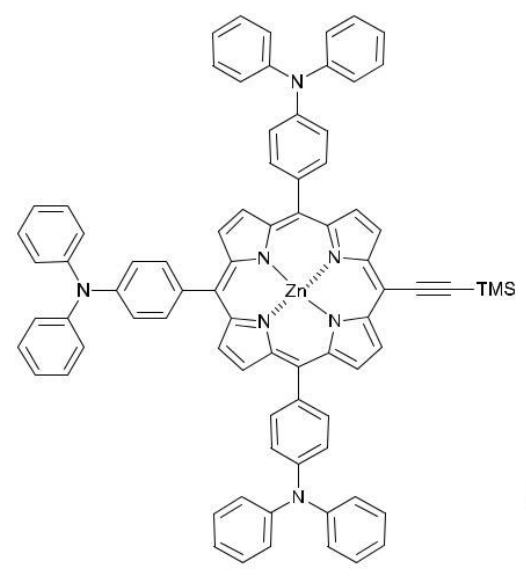

2

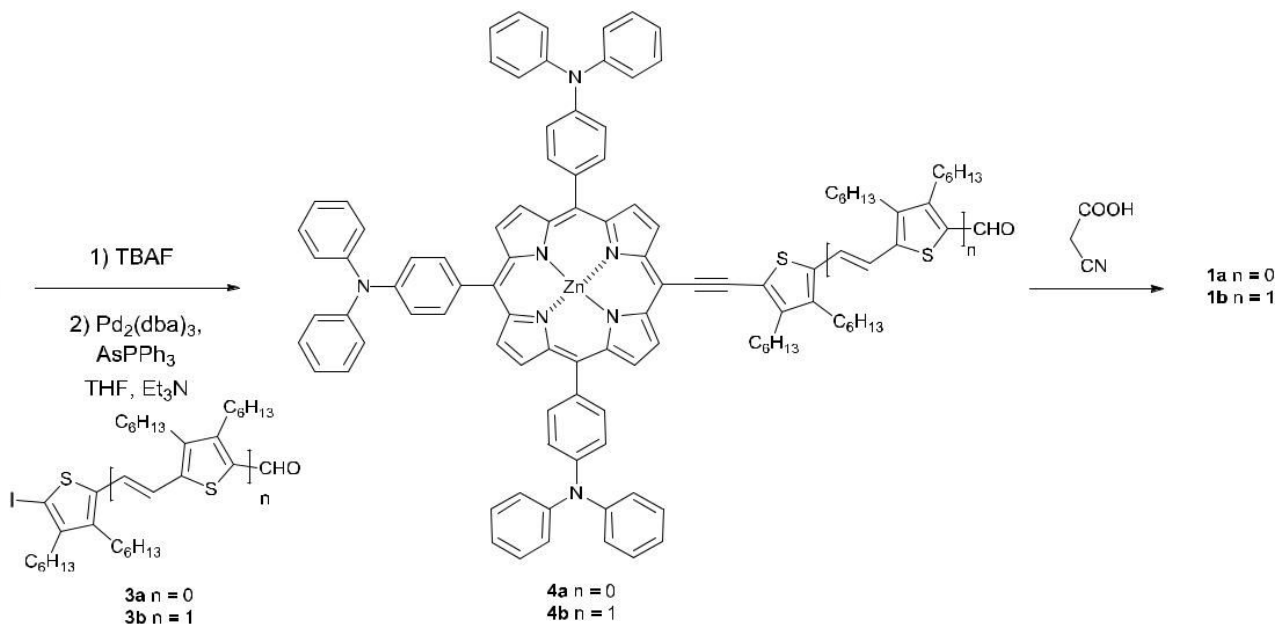

Scheme 1. Synthetic route to dyes $1 \mathrm{a}$ and $1 \mathrm{~b}$. 
appeared at $523 \mathrm{~nm}(\log \varepsilon 1 / 44.87)$, which is attributed to the conjugated oligomer bridge. Furthermore, the ICT band was observed at $668 \mathrm{~nm}(\log \varepsilon 1 / 4$ 4.91) with an increased absorption coefficient (see Fig. 2 and Table 1).

The steady state fluorescence spectra of dyes $1 a, b$ measured in THF show an emission band at $703 \mathrm{~nm}$ in both cases (1a $1_{\text {exc }} 1 / 4471 \mathrm{~nm}$ and $1 \mathrm{~b} 1_{\text {exc }} 1 / 4$ $460 \mathrm{~nm}$ ) (Fig. S19). It is also noteworthy that significant differences were not observed in the emission band as a result of the increased conjugation due to the inclusion of an additional thienylenevinylene unit. The emission bands were totally quenched after adsorption onto $\mathrm{TiO}_{2}$ and this suggests an efficient photoinduced electron transfer from the excited state of the dye to the $\mathrm{TiO}_{2}$ nanoparticles (Fig. S20).

\subsection{Electrochemical properties}

The redox properties of $1 \mathrm{a}, \mathrm{b}$ were investigated by cyclic vol-tammetry and square wave voltammetry in THF (Table 1, Figs S21 and S22). On the cathodic side, compounds $1 \mathrm{a}, \mathrm{b}$ show the first irreversible oxidation peaks at 0.29 and $0.26 \mathrm{~V}\left(\mathrm{vs} \mathrm{Fc} / \mathrm{Fc}^{\mathrm{p}}\right.$ ), respectively. This first oxidation potential is assigned to the porphyrin core and the extended conjugation gives rise to a decrease in the $\mathrm{E}_{\mathrm{OX}}$ value by $30 \mathrm{mV}$ in $1 \mathrm{~b}$ in comparison to $1 \mathrm{a}$. The other oxidation processes are attributed to the thienylenevinylene units. On the reduction side, the two compounds show first reduction potentials at $1.62 \mathrm{~V}$ and $1.71 \mathrm{~V}$, respectively, as irre-versible waves, and these are attributed to the reduction of the thienylenevinylene moieties. A second reduction potential was also observed at $1.76 \mathrm{~V}$ for $1 \mathrm{a}$ and this is attributed to the reduction of the porphyrin core. This second reduction potential was also observed in the case of $1 \mathrm{~b}$ as a shoulder on the first reduction wave. The EHOMO values deduced from the oxidation potentials are $5.39 \mathrm{eV}$ and $5.36 \mathrm{eV}$ for $1 \mathrm{a}$ and $1 \mathrm{~b}$, respectively, and these indicate that the regeneration is energetically feasible by $\mathrm{I}_{\mathrm{I}} \mathrm{e}_{3}\left(\mathrm{E}_{\text {redox }}{ }^{1 / 4} 4.75 \mathrm{eV}\right.$ ). The ELUMO values, e 3.56 for $1 \mathrm{a}$ and 3.54 for $1 \mathrm{~b}$, also indicate that efficient electron injection into the $\mathrm{TiO}_{2}$ conduction band $\left(\mathrm{E}_{\mathrm{TiO} 2} 1 / 44.00 \mathrm{eV}\right)$ is energetically possible.

\subsection{Theoretical calculations}

In order to gain an insight into the geometrical and electronic properties of dyes $1 \mathrm{a}$ and $1 \mathrm{~b}$, DFT calculations were performed at the B3LYP/6-31G(d) level in vacuo with Gaussian $03 \mathrm{~W}$.

The calculated ground state geometries (Fig. 3) for both dyes (1a and 1b) show that the meso-substituted aryl rings are twisted with respect to the macrocyclic Zn-porphyrin core, with a dihedral angle of around $61 \mathrm{e} 63$. The phenyl groups bonded to the nitrogen atoms

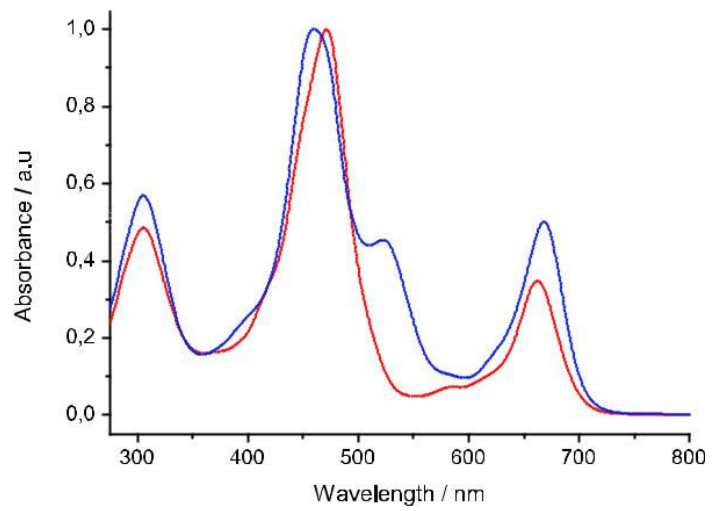

Fig. 2. Normalised absorption spectra of dyes $1 \mathrm{a}(\boldsymbol{E})$ and $1 \mathrm{~b}\left(\right.$ ) in THF solution $\left(10^{6} \mathrm{M}\right)$. of the TPAs have a dihedral angle of around 42 . As a consequence, the triphenylamine units act as bulky groups that make aggregation through $\mathrm{p}-\mathrm{p}$ stacking of the dyes more difficult. This characteristic improves the photoelectron injection efficiency from the dye to the $\mathrm{TiO}_{2}$ electrode and, as a consequence, increases the conversion ef-ficiency. On the other hand, the thiophene fragments of dyes $1 \mathrm{a}, \mathrm{b}$, which include the anchor group, lie in the same plane as the porphyrin core. In dye $1 \mathrm{~b}$ the planarity between the macrocycle and the thiophene ring, which is bound to the triple bond, is slightly greater $(4 \mathrm{z} 5)$ than that in dye $1 \mathrm{a}(4 \mathrm{z} 8)$. This planarity be-tween the porphyrin and the anchor group ensures effective elec-tron coupling between the two electroactive fragments. The bond distances in the conjugated systems based on thiophene are around $1.40 \AA$, both double and single, and this provides evidence of the pushepull character and the effective conjugation between the porphyrin and the anchor group.

The molecular orbital analysis of the frontier orbitals of dyes $1 a, b$ together with their energy levels are shown in Fig. 4. The HOMO-LUMO energy levels and consequently the HOMO-LUMO energy gap of dyes 1a $(1.99 \mathrm{eV})$ and $1 \mathrm{~b}(1.88 \mathrm{eV})$ are very similar, but $1 \mathrm{~b}$ has a somewhat more stable HOMO energy level and a LUMO about $0.06 \mathrm{eV}$ higher than that of 1a. Nevertheless, these types of sensi-tizers have sufficient driving force for electron injection to $\mathrm{TiO}_{2}$.

The electron distributions of dyes $1 \mathrm{a}$ and $1 \mathrm{~b}$ (Fig. 4) indicate that the HOMO levels are mainly localized over the porphyrin macro-cycle with some delocalization onto the nTV fragments and the anchor group. The HOMO-1 and HOMO-2 are confined to the tri-phenylamine units.

The first two LUMO orbitals are scattered along the porphyrin ring, the thiophene units and the anchor group. The LUMOp1 of dye 1a is exclusively distributed on the porphyrin ring whereas some of the electron density of LUMOp1 of dye $1 \mathrm{~b}$ is spread throughout the whole conjugated system, even on the anchor group.

The above findings are consistent with the data obtained in the electrochemical studies. The first oxidation potential (1a: $\mathrm{E}_{\text {ox }}^{1} 1 / 40.29 \mathrm{~V} ; 1 \mathrm{~b}$ : $0.26 \mathrm{~V}$ ) corresponds to the formation of the porphyrin radical cation and the second is due to the oxidation of the triphenylamino substituents $\left(E^{1}\right.$ ox $z \quad 0.5$ $\mathrm{V})$ in both dyes $[10,21]$. The reduction processes occur throughout the whole conjugated system but in dye $1 \mathrm{~b}$ the second reduction potential observed is due to the reduction of the porphyrin macrocycle (see electro-chemical studies).

\subsection{Characterisation of the solar cells}

Two different sets of porphyrin sensitized solar cells were pre-pared depending on the electrolyte used. The electrolytes were

Table 1

UV-Vis, ${ }^{\mathrm{a}}$ Fluorescence Emission ${ }^{\mathrm{a}}$ and $\mathrm{OSWV}^{\mathrm{b}}$ data for compounds $1 \mathrm{aeb}$

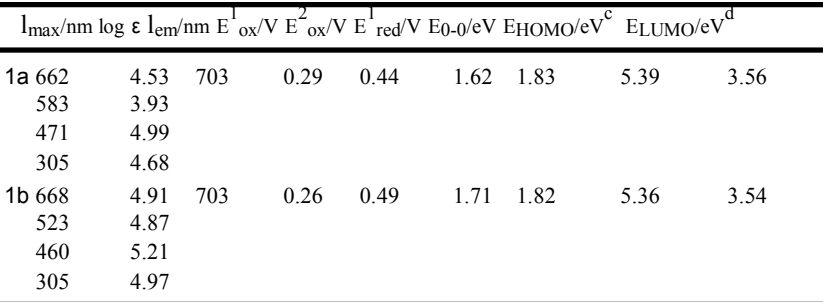

a 1a: $8.7010{ }^{6} \mathrm{M}$, THF; 1b: $5.15 \quad 10{ }^{6} \mathrm{M}$, THF

b $\left[10^{3} \mathrm{M}\right]$ in THF versus $\mathrm{Fe} / \mathrm{Fcp}$, glassy carbon, Pt counter electrode, $20 \mathrm{C}, 0.1 \mathrm{M}$ $\mathrm{Bu}_{4} \mathrm{NClO}_{4}$, scan rate $1 / 4100 \mathrm{mV} \mathrm{s}$.

c Calculated using the equation EHOMO (vs. vacuum) $1 / 45.1 \mathrm{e} \mathrm{E}_{\text {ox }}^{1}\left(\mathrm{vs} . \mathrm{Fc} / \mathrm{Fc}^{\mathrm{p}}\right)$ in $\mathrm{eV}$ [25].

d ELUMO was calculated using ELUMO $1 / 4$ EHOMO $p E_{0-0}$, where $E_{0-0}$ is the intersection of the absorption and emission spectra. 


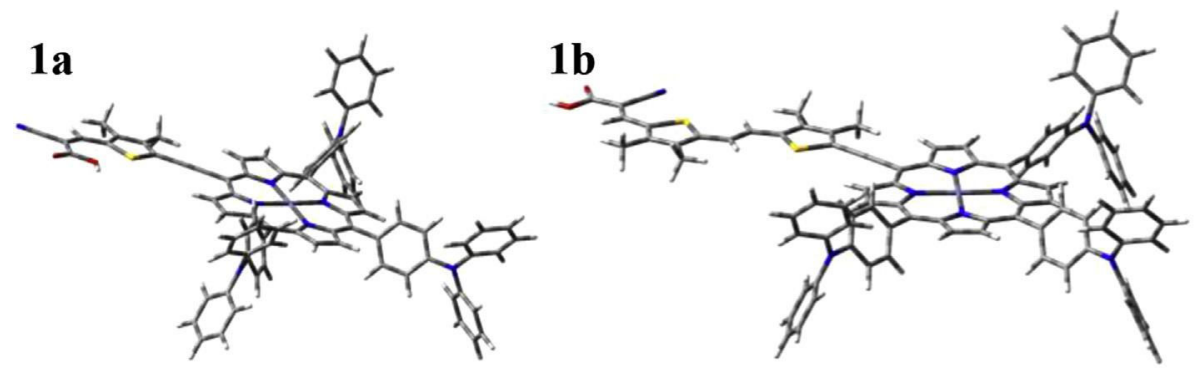

Fig. 3. Structures of dyes $1 \mathrm{a}$ (left) and $1 \mathrm{~b}$ (right) optimized at the B3LYP/6-31G(d) level.

denoted as LP1 and LP2 (see Experimental Section) and they differed only in the presence of $0.5 \mathrm{M}$ tert-butyl pyridine (TBP) in LP1. The current vs. voltage (IV curves) under $100 \mathrm{~mW} / \mathrm{cm}^{2}$ sun (1.5 AMG) simulated light are shown in Fig. 5. As can be seen, there is a marked difference in the device open circuit voltage $\left(\mathrm{V}_{\mathrm{Oc}}\right)$ between the two porphyrin sensitized $\mathrm{TiO}_{2}$ solar cells using the different electrolytes (Table 2).

Subsequent measurements aimed at characterising the solar cells were carried out to analyse the differences in photocurrent. The IPCE (Incident Photon to Current Efficiency) measurements (Fig. 6) are in good agreement with the registered $\mathrm{J}_{\mathrm{Sc}}$ values under 1 sun (Table 2). As can be observed, in all measurements two bands can be clearly differentiated and these correspond to the Soret band of the porphyrins and the ICT band. Integration of the IPCE spec-trum with respect to the $1.5 \mathrm{AM} \mathrm{G}$ solar spectrum gave the expected photocurrent of $13 \mathrm{~mA} / \mathrm{cm}^{2}$ for $1 \mathrm{a}$ on using electrolyte LP1 and 12.8 $\mathrm{mA} / \mathrm{cm}^{2}$ for $1 \mathrm{~b}$ on using electrolyte LP2.

Photo-induced charge recombination studies were carried out to analyse the differences in $\mathrm{V}_{\mathrm{Oc}}$.
Firstly, the charge density (total charge upon different light irradiation) was measured using the photo-induced charge extrac-tion method, which has been reported previously [12]. The different exponential curves obtained with different light bias values (cell voltage upon different light illumination intensities) are shown in Fig. 7. As one would expect, the use of 4-TBP with the LP1 electrolyte leads to a shift in the measured curves towards higher $\mathrm{V}_{\mathrm{OC}}$ e a finding in agreement with previous literature data [26]. The use of 4-TBP induces an up-shift in the conduction band (CB) edge of the $\mathrm{TiO}_{2}$ and this leads to an increase in cell voltage. Interestingly, for porphyrin 1a the shift in the $\mathrm{CB}$ edge of the $\mathrm{TiO}_{2}$ did not lead to a concomitant decrease in the cell $\mathrm{J}_{\mathrm{Sc}}$ value as a consequence of the more unfavourable electron transfer from the dye excited state to the $\mathrm{TiO}_{2} \mathrm{CB}$, which is the case for porphyrin $1 \mathrm{~b}$. This result led the authors to consider that the presence of 4-TBP, in combination with porphyrin $1 \mathrm{a}$, results in a better charge transfer from the dye excited state due to a lower concentration of $1 \mathrm{~b}$ molecular aggregates.

Measurement of the electron lifetimes for the different set of solar cells (Fig. 8) shows that for solar cells sensitized with 1a the

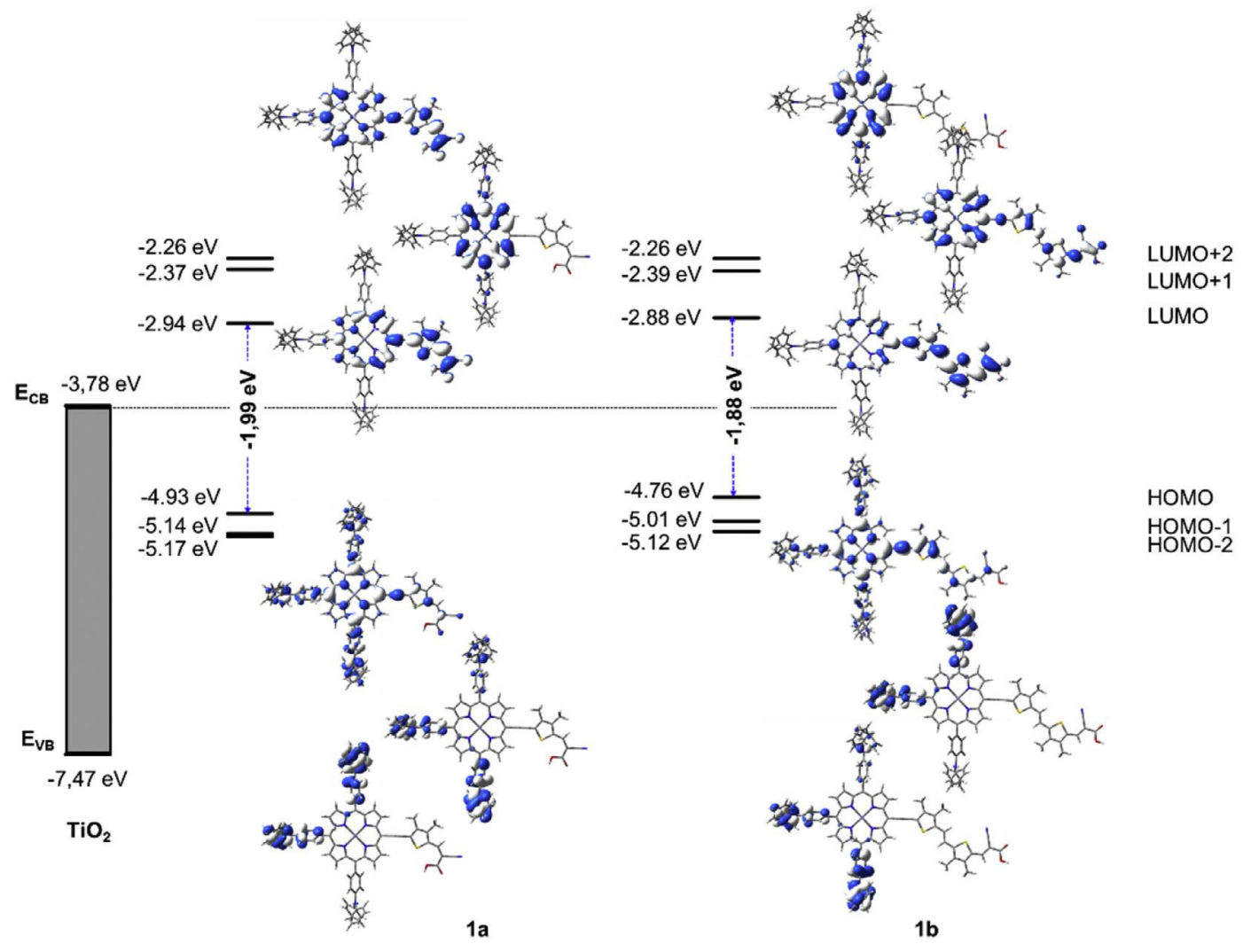

Fig. 4. Energy levels of occupied and unoccupied MO and the electron density distribution of the corresponding frontier orbitals calculated at the B3LYP/6-31G(d) level. 


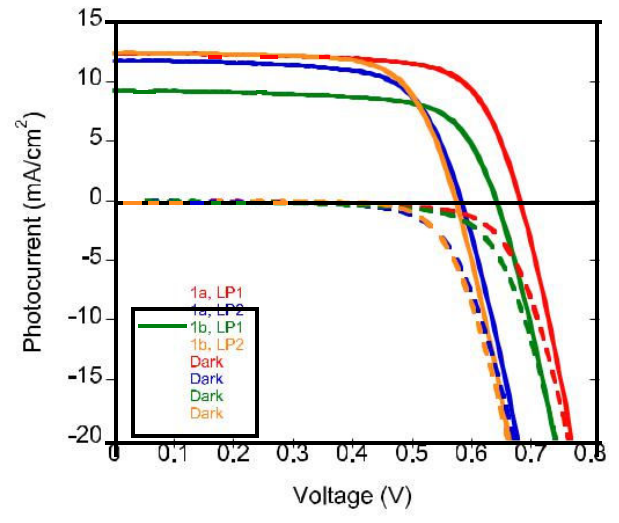

Fig. 5. Current vs. Voltage measurements for the two different DSSC (cell area $0.16 \mathrm{~cm}^{2}$ ). Dashed lines correspond to measurements made in the dark.

factor that has the most marked effect on solar cell performance is the use of 4-TBP in the electrolyte. It is noticeable that the presence of 4-TBP in the LP1 electrolyte leads to slower charge recombina-tion kinetics between the electrons at the $\mathrm{TiO}_{2}$ and the oxidised electrolyte when compared to the solar cells based on $1 \mathrm{a}$ with the electrolyte LP2. In contrast, for porphyrin $1 \mathrm{~b}$ the presence of 4-TBP does not have an influence on the electron lifetime and in both cases a similar value was obtained. Thus, the higher $\mathrm{V}_{\mathrm{Oc}}$ obtained for DSSC sensitized with $1 \mathrm{~b}$ and the electrolyte LP1 is due to the up-shift of the $\mathrm{TiO}_{2} \mathrm{CB}$ edge and not to slower charge combination kinetics between the photo-injected electrons on the $\mathrm{TiO}_{2}$ and the oxidised electrolyte.

\section{Conclusions}

Two related porphyrin sensitizers were designed and sensitized for use in efficient DSSC. The two compounds differ in the number of thiophene moieties. Moreover, the performance of these mate-rials was studied using different electrolytes that differed only in the presence or absence of 4-TBP. For porphyrin 1a the presence of 4-TBP in the electrolyte proved to be beneficial, as reported previ-ously for other organic dyes. The expected shift in the $\mathrm{TiO}_{2}$ con-duction band edge was observed and this led to a concomitant increase in the solar cell $\mathrm{V}_{\mathrm{oc}}$. Unexpectedly, an increase in the solar cell photocurrent was also observed and this behaviour is not seen often when using 4-TBP. The increase in the photocurrent was further confirmed by measuring the IPCE. The logical explanation for the increase in photocurrent, despite the up-shift in the $\mathrm{TiO}_{2} \mathrm{CB}$ edge, is that in this particular case the presence of 4-TBP led to the formation of fewer 1a molecular aggregates, which in turn enhanced the electron transfer process from the excited state of the molecule into the $\mathrm{TiO}_{2} \mathrm{CB}$.

In the case of porphyrin $1 \mathrm{~b}$, the presence of 4-TBP also led to an increase in the solar cell $\mathrm{V}_{\mathrm{Oc}}$ for the reason explained above but, in this case, a decrease in the photocurrent was not observed $\mathrm{e}$ a

Table 2

Measured parameters for the optimised DSSC in Fig. 5.

\begin{tabular}{lllclll}
\hline Cell & Electrolyte & $\begin{array}{l}\text { Sensitization } \\
\text { time (hours) }\end{array}$ & $\mathrm{J}_{\mathrm{sc}}\left(\mathrm{mA} / \mathrm{cm}^{2}\right)$ & $\mathrm{V}_{\mathrm{oc}}(\mathrm{V})$ & $\mathrm{FF}(\%)$ & $\mathrm{h}(\%)$ \\
\hline 1a & LP1 & 3 & 12.3 & 0.684 & 71 & 6.0 \\
1a & LP2 & 3 & 11.7 & 0.584 & 68 & 4.7 \\
1b & LP1 & $1^{\mathrm{a}}$ & 9.20 & 0.644 & 70 & 4.1 \\
1b & LP2 & 3 & 12.35 & 0.574 & 70 & 5.0 \\
\hline
\end{tabular}

${ }^{\mathrm{a}}$ Longer sensitization times led to lower photocurrent and worse device per-formance. FF (Fill Factor). h (solar-to-electrical current efficiency).

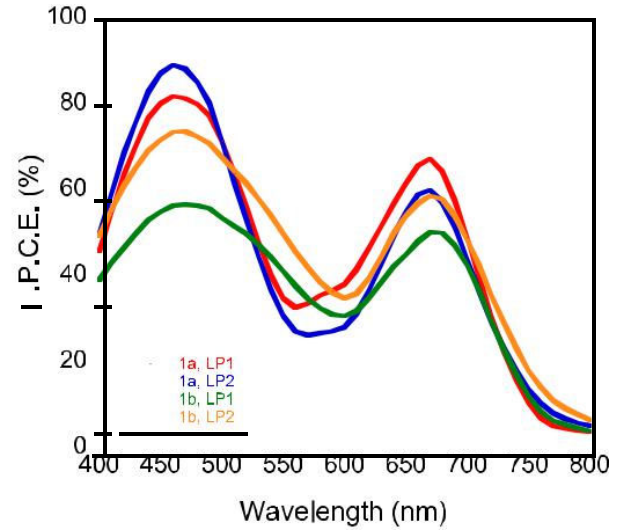

Fig. 6. IPCE measurements for the optimized DSSC.

finding that was attributed to the up-shift of the $\mathrm{TiO}_{2} \mathrm{CB}$ leading to less favourable charge transfer from the porphyrin excited state to the $\mathrm{TiO}_{2} \mathrm{CB}$. In fact, the presence of 4-TBP did not slow the lifetime of the electrons in this case.

\section{Experimental}

\subsection{General procedure for the synthesis of $4 a$ and $4 b$}

To a solution of [10,15,20-tri-(N,N-diphenylaniline)-5ethynyltrimethylsilane]porphyrinate zinc(II) $2(1 \mathrm{mmol})$ in $\mathrm{CH}_{2} \mathrm{Cl}_{2}$ (200 $\mathrm{mL} / \mathrm{mmol}$ ) was added under argon TBAF (1.25 mmol, $1 \mathrm{M}$ in THF). The solution was stirred at room temperature for $1 \mathrm{~h}$. The mixture was quenched with $\mathrm{H}_{2} \mathrm{O}$ and extracted with $\mathrm{CH}_{2} \mathrm{Cl}_{2}$ (3 $50 \mathrm{~mL}$ ). The combined organic layers were dried over anhy-drous $\mathrm{MgSO}_{4}$ and the solvent was removed under reduced pres-sure. The residue, which was used without further purification, and 3aeb (3 mmol) were dissolved in dry THF $(230 \mathrm{~mL} / \mathrm{mmol})$ and $\mathrm{Et}_{3} \mathrm{~N}$ (45 mL/mmol). The solution was degassed with argon for $15 \mathrm{~min}$ and $\mathrm{Pd}_{2}(\mathrm{dba})_{3}(0.3 \mathrm{mmol})$ and $\mathrm{AsPh}_{3}(2 \mathrm{mmol})$ were added to the mixture. The solution was heated under reflux overnight. The sol-vent was removed under reduced pressure. The product was pu-rified by column chromatography (silica gel, hexane: $\mathrm{CHCl} 3,1: 1$ ).

\subsection{Synthesis of $4 a$}

[10,15,20-Tri-(N,N-diphenylaniline)-5-ethynyltrimethylsilane] porphyrinate zinc(II) $(110 \mathrm{mg}, 0.09 \mathrm{mmol})$ was reacted according to the general procedure to give $4 \mathrm{a}(107 \mathrm{mg})$ as a green solid

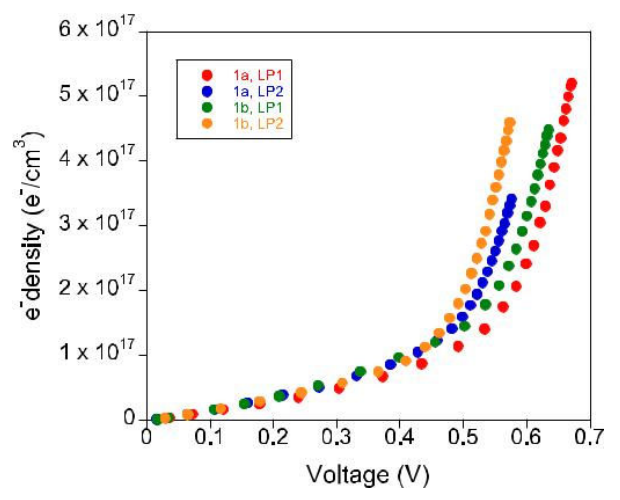

Fig. 7. Photo-induced charge extraction measurements for all DSSC (cell area $0.16 \mathrm{~cm}^{2}$ ). 


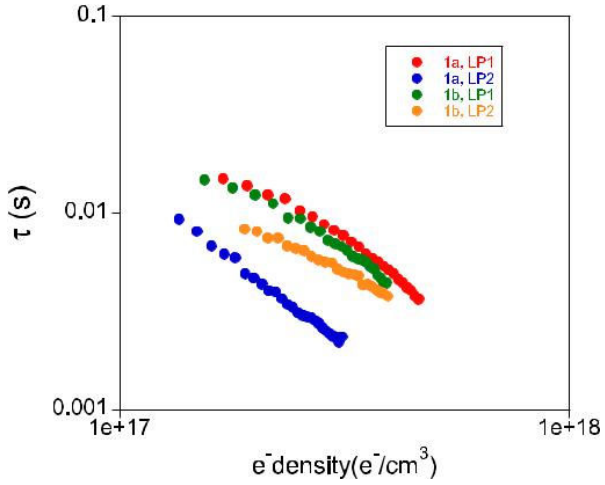

Fig. 8. Electron lifetimes measured using TPV vs device charge density at different light bias for all different DSSC.

(0.076 mmol, 83\% yield). ${ }^{1} \mathrm{H}$ NMR (400 MHz, $\left.\mathrm{CDCl}_{3}\right) \mathrm{d} / \mathrm{ppm}: 9.90$ (s, $\left.1 \mathrm{H}\right)$, $9.73(\mathrm{~d}, \mathrm{~J} 1 / 44.7 \mathrm{~Hz}, 2 \mathrm{H}), 9.16(\mathrm{~d}, \mathrm{~J} 1 / 44.7 \mathrm{~Hz}, 2 \mathrm{H}), 9.05$ (d, J $1 / 44.7 \mathrm{~Hz}, 2 \mathrm{H})$, $9.03(\mathrm{~d}, \mathrm{~J} 1 / 44.7 \mathrm{~Hz}, 2 \mathrm{H}), 8.07(\mathrm{t}, \mathrm{J} 1 / 48.7 \mathrm{~Hz}, 6 \mathrm{H}), 7.50 \mathrm{e} 7.42(\mathrm{~m}, 6 \mathrm{H})$, $7.49 \mathrm{e} 7.38(\mathrm{~m}, 24 \mathrm{H}), 7.16 \mathrm{e} 7.11(\mathrm{~m}, 6 \mathrm{H}), 2.97(\mathrm{~m}, 2 \mathrm{H}), 2.78(\mathrm{~m}, 2 \mathrm{H}), 1.94(\mathrm{~m}$, $2 \mathrm{H}), 1.72 \mathrm{e} 1.62(\mathrm{~m}, 4 \mathrm{H}), 1.50 \mathrm{e} 1.46(\mathrm{~m}, 4 \mathrm{H}), 1.41 \mathrm{e} 1.36(\mathrm{~m}, 6 \mathrm{H}), 0.95(\mathrm{t}, \mathrm{J} 1 / 4$ $7.1 \mathrm{~Hz}, 3 \mathrm{H}), 0.88(\mathrm{t}, \mathrm{J} 1 / 47.1 \mathrm{~Hz}, 3 \mathrm{H}) .{ }^{13} \mathrm{C} \mathrm{NMR}\left(100 \mathrm{MHz}, \mathrm{CDCl}_{3}\right) \mathrm{d} / \mathrm{ppm}$ : $181.67,152.00,151.26,151.16,151.00,147.87,147.84,147.69,147.52$, $137.18,136.17,136.00,135.38,135.34,133.27,132.44,132.00,130.35$, $129.53,124.91,123.32,122.45,121.33,121.26,32.27,31.86,31.54,30.95$, $29.86,29.39,28.60,22.81,22.61,14.15,14.12$. FT-IR n/cm ${ }^{1}: 2957,2922$, 2855, 1652, 1590, 1489, 1318, 1282, 996, 696. MS (m/z) (MALDI-TOF): calculated for $\mathrm{C}_{93} \mathrm{H}_{77} \mathrm{~N}_{7} \mathrm{OSZn}$ : 1403.52; found: 1403.90. MP: $180 \mathrm{e} 182 \mathrm{C}$.

\subsection{Synthesis of $4 b$}

[10,15,20-Tri-(N,N-diphenylaniline)-5-ethynyltrimethylsilane porphyrinate zinc(II) $2(130 \mathrm{mg}, 0.11 \mathrm{mmol})$ was reacted ac-cording to the general procedure to give $4 \mathrm{~b}(135 \mathrm{mg})$ as a green solid $(0.080 \mathrm{mmol}, 80 \%$ yield). ${ }^{1} \mathrm{H}$ NMR (400 MHz, $\left.\mathrm{CDCl}_{3}\right) \mathrm{d} / \mathrm{ppm}: 9.84(\mathrm{~s}, 1 \mathrm{H}), 9.78(\mathrm{~d}, \mathrm{~J} 1 / 44.6 \mathrm{~Hz}$, 2H), 9.14 (d, J 1 1 4 4.6 Hz, 2H), 9.03 (dd, J 1/4 4.6, 6.7 Hz, 4H), 8.07 (dd, J 1 1/4 7.6, 9.7 Hz, 6H), 7.49 (d, J 1/4 8.6 Hz, 6H), 7.45e7.41 (m, 24H), 7.32 (d, J 1/4 $15.5 \mathrm{~Hz}, 1 \mathrm{H}), 7.19 \mathrm{e} 7.13(\mathrm{~m}, 6 \mathrm{H}), 7.08(\mathrm{~d}, \mathrm{~J} 1 / 415.5 \mathrm{~Hz}, 1 \mathrm{H}), 3.13(\mathrm{dd}, \mathrm{J} 1 / 4$ 6.0, 10.0 Hz, 2H), $2.77(\mathrm{t}, \mathrm{J} 1 / 47.0 \mathrm{~Hz}, 2 \mathrm{H}), 2.74(\mathrm{t}, \mathrm{J} 1 / 47.0 \mathrm{~Hz}, 2 \mathrm{H}), 2.61(\mathrm{dd}$, J $1 / 46.0,10.0 \mathrm{~Hz}, 2 \mathrm{H}), 2.00(\mathrm{q}, \mathrm{J} 1 / 47.0 \mathrm{~Hz}, 2 \mathrm{H}), 1.78 \mathrm{e} 1.52(\mathrm{~m}, 12 \mathrm{H})$ $1.46 \mathrm{e} 1.33(\mathrm{~m}, 18 \mathrm{H}), 1.02 \mathrm{e} 0.86(\mathrm{~m}, 12 \mathrm{H}) .{ }^{13} \mathrm{C}$ NMR $\left(100 \mathrm{MHz}, \mathrm{CDCl}_{3}\right)$ $\mathrm{d} / \mathrm{ppm}: 181.82,152.97,151.85,150.78,150.28,149.90,148.34,147.89$, $147.86,147.46,146.82,142.77,141.93,137.17,136.30,136.18,135.38$, $134.78,132.94,138.28,131.96,130.47,129.52,124.86,123.28,122.91$, $122.18,121.40,121.31,119.24,118.90,32.30,31.95,31.71,31.66,31.57$, $31.25,29.93,29.50,29.42,27.58,27.12,22.84,22.72,22.70,22.60,14.24$, 14.18, 14.10. FT-IR n/cm ${ }^{1}: 3030,2952,2921,2850,1650,1589,1487,1311$, 1276, 995, 696. MS (m/z) (MALDI-TOF): calculated for $\mathrm{C}_{111} \mathrm{H}_{105} \mathrm{~N}_{7} \mathrm{OS}_{2} \mathrm{Zn}: 1679.71$; found: 1680.10 . MP: $177 \mathrm{e} 178 \mathrm{C}$.

\subsection{General procedure for Knoevenagel condensations}

To a solution of 4aeb $(1 \mathrm{mmol})$ in $20 \mathrm{~mL} / \mathrm{mmol}$ of $\mathrm{CHCl}_{3}$ were added cyanoacetic acid $(1.5 \mathrm{mmol})$ and piperidine $(0.1 \mathrm{mmol})$. The reaction mixture was heated under reflux under argon for $18 \mathrm{~h}$. The solvent was removed and the residue was purified by column chromatography on silica gel with $\mathrm{CHCl}_{3} / \mathrm{MeOH}$ 10:1 mixture as the eluent.
4.4.1. Synthesis of $[10,15,20$-tri( $N, N$-diphenylaniline)-5-(2-cyano-3-(3,4dihexyl-5-ethynyl)thiophene-2-yl)acrylic acid)porphyrinate] zinc(II) (1a)

Compound $4 \mathrm{a}(60 \mathrm{mg}, 0.043 \mathrm{mmol})$ was reacted according to the general procedure to give $1 \mathrm{a}(56 \mathrm{mg})$ as a green solid $(0.038 \mathrm{mmol}, 89 \%$ yield). ${ }^{1}$ H NMR (500 MHz, THF-d8) d/ppm: 9.72 (d, J 1/4 $\left.4.2 \mathrm{~Hz}, 2 \mathrm{H}\right), 9.06$ (s broad, 2H), 8.94e $8.90(\mathrm{~m}, 4 \mathrm{H}), 8.54(\mathrm{~s}, 1 \mathrm{H}), 8.05(\mathrm{~d}, \mathrm{~J} 1 / 48.1 \mathrm{~Hz}, 6 \mathrm{H}), 7.45$ (d, J $1 / 48.1 \mathrm{~Hz}, 6 \mathrm{H}), 7.40 \mathrm{e} 7.39(\mathrm{~m}, 24 \mathrm{H}), 7.13 \mathrm{e} 7.96(\mathrm{~m}, 6 \mathrm{H}), 3.29(\mathrm{~m}, 2 \mathrm{H})$, $3.00(\mathrm{~m}, 2 \mathrm{H}), 2.08(\mathrm{~m}, 2 \mathrm{H})$,

$1.77(\mathrm{~m}, 2 \mathrm{H}), 1.61 \mathrm{e} 1.50(\mathrm{~m}, 6 \mathrm{H}), 1.47 \mathrm{e} 1.41(\mathrm{~m}, 6 \mathrm{H}), 0.98$ (s broad, 3H), 0.87 (s broad, $3 \mathrm{H}) .{ }^{13} \mathrm{C}$ NMR (125 MHz, THF-d8) d/ppm: 151.59, 150.75, 150.55, $148.82,148.79,148.24,147.13,137.78,137.62,136.24,133.38,132.47$, $131.99,130.47,130.11,125.48,125.45,124.01,123.90$,

$123.85,122.80,121.99,121.82,32.84,32.69,32.57,31.80,31.55,30.58$, $30.44,30.28,23.51,23.45,14.34$. FT-IR n/cm ${ }^{1}: 3419,3068,3033,2955$, 2925, 2155, 1600, 1495, 1386, 1317, 1282, 698. MS (m/z) (MALDI-TOF): calculated for $\mathrm{C}_{96} \mathrm{H}_{78} \mathrm{~N}_{8} \mathrm{O}_{2} \mathrm{SZn}$ : 1470.53 ; found: 1470.96 . MP: $185 \mathrm{e} 187 \mathrm{C}$.

4.4.2. Synthesis of $[10,15,20$-tri(N,N-diphenylaniline)-5-(2-cyano3-(5-((E-2-(3,4-dihexyl-5-(ethynyl)thiophen-2-yl)vinyl)-3,4dihexylthiophene-2-yl)acrylic acid)porphyrinate] zinc(II) (1b)

Compound $4 \mathrm{~b}(130 \mathrm{mg}, 0.078 \mathrm{mmol})$ was reacted according to the general procedure to give $1 \mathrm{~b}(110 \mathrm{mg})$ as a green solid $(0.063 \mathrm{mmol}, 82 \%$ yield). ${ }^{1} \mathrm{H}$ NMR (500 MHz, THF-d8) d/ppm: 9.73 (d, J 1/4 4.4 Hz, 2H), 9.05 (d, J $1 / 44.4 \mathrm{~Hz}, 2 \mathrm{H}), 8.94 \mathrm{e} 8.91(\mathrm{~m}, 4 \mathrm{H}), 8.45(\mathrm{~s}, 1 \mathrm{H}), 8.06(\mathrm{t}, \mathrm{J} 1 / 48.6 \mathrm{~Hz}, 6 \mathrm{H})$, $7.45(\mathrm{t}, \mathrm{J} 1 / 48.6 \mathrm{~Hz}, 6 \mathrm{H}), 7.41 \mathrm{e} 7.38(\mathrm{~m}, 25 \mathrm{H}), 7.30(\mathrm{~d}, \mathrm{~J}$ 1/4 $15.4 \mathrm{~Hz}, 1 \mathrm{H})$, $7.13 \mathrm{e} 7.09(\mathrm{~m}, 6 \mathrm{H}), 3.24(\mathrm{~m}, 2 \mathrm{H}), 2.91(\mathrm{~m}, 2 \mathrm{H}), 2.82(\mathrm{~m}, 4 \mathrm{H}), 2.07(\mathrm{~m}, 2 \mathrm{H})$, $1.78(\mathrm{~m}, 2 \mathrm{H}), 1.65(\mathrm{~m}, 4 \mathrm{H}), 1.56(\mathrm{~m}, 8 \mathrm{H}), 1.50 \mathrm{e} 1.36(\mathrm{~m}, 16 \mathrm{H}), 1.03 \mathrm{e} 0.93(\mathrm{~m}$, 9H), 0.89 (t, J $1 / 47.2 \mathrm{~Hz}, 3 \mathrm{H}) .{ }^{13} \mathrm{C}$ NMR $(125 \mathrm{MHz}$, THF-d8) d/ppm: 151.45 , $150.85,150.47,148.83,148.80,148.44,148.21,137.86,137.74,136.25$, $136.22,133.09,132.36,132.02,130.48,130.11,125.46,125.45,123.87$, $123.86,122.55,121.99,121.85,32.75,32.50,32.43,32.30,32.01,31.90$, $30.60,30.45,30.13,30.07,29.95,23.55,23.46,23.40,14.41,14.37$. FT-IR $\mathrm{n} / \mathrm{cm}^{1}:$ : 3389, 3059, 3032, 2950, 2932, 2924, 2855, 1595, 1564, 1491, 1386, 1277, 978, 796, 752, 691. MS (m/z) (MALDI-TOF): calculated for $\mathrm{C}_{114} \mathrm{H}_{106} \mathrm{~N}_{8} \mathrm{O}_{2} \mathrm{~S}_{2} \mathrm{Zn}: 1746.72$; found: 1747.17. MP: $182 \mathrm{e} 184{ }^{\mathrm{a}} \mathrm{C}$.

\section{Device preparation and characterisation}

The working electrodes for the best devices were made using $8 \mathrm{~mm}$ thick transparent mesoporous $\mathrm{TiO}_{2}$ and $4 \mathrm{~mm}$ thick $\mathrm{TiO}_{2}$ layer, so-called $8 \mathrm{p} 4$, deposited onto fluorine-doped tin-oxide glass (FTO, Pilkington Glass Inc., with $15 \mathrm{Ohms} /$ square sheet resistance). The counter electrode was fabricated using the same FTO with a ther-malized Pt layer from $\mathrm{H}_{2} \mathrm{PtCl}_{6}$ ( $8 \%$ in water). The subsequent steps to prepare the complete devices, as well as the photocurrent vs voltage (IV curves), charge extraction and photo-induced transient photovoltage have been published previously.

Photo-induced charge extraction was carried out as described in a previous publication [26]. In brief, white light from a series of LEDs was used as the light source. When the LEDs were turned off, the cell was immediately short-circuited and the charge was extracted, thus allowing the electron density in the cells to be calculated. By changing the intensity of the LEDs, the electron density can be estimated as a function of cell voltage. In photoinduced transient photovoltage (TPV) measurements, in addition to the white light applied by the LEDs, a diode pulse $(660 \mathrm{~nm}, 10 \mathrm{~mW})$ was applied to the sample to induce a change of $2 \mathrm{e} 3 \mathrm{mV}$ within the cell. The resulting photovoltage decay transients were collected and the $t$ values were determined by fitting the data to the equation $\exp (t / t)$. 


\subsection{Computational methods}

The details for the computational methods can be found in the supplementary information.

\section{Acknowledgements}

The ICIQ authors would like to thank MINECO for projects CTQ201347183 and the Severo Ochoa Excellence Accreditation 2014e2018 (SEV2013-0319). EP also thanks AGAUR for the SGR project 2014 SGR 763 and ICIQ and ICREA for economical support. The UCLM authors would like to thank MINECO for project CTQ2013-48252-P and Junta de Comunidades de Castilla-La Man-cha (project PEII-2014-014-P). SA thanks to the Fundacion Carolina for a grant.

\section{Appendix A. Supplementary data}

Supplementary data related to this article can be found at http:// dx.doi.org/10.1016/j.dyepig.2015.11.002.

\section{References}

[1] Yella A, Lee H-W, Tsao HN, Yi C, Chandiran AK, Nazeeruddin MK, et al. Science 2011;334:629e34.

[2] Joly D, Pelleja L, Narbey S, Oswald F, Meyer T, Kervella Y, et al. Energy Environ Sci 2015;8:2010e8.

[3] Clifford JN, Martinez-Ferrero E, Viterisi A, Palomares E. Chem Soc Rev 2011;40:1635e46.

[4] Martinez-Diaz MV, de la Torre G, Torres T. Chem Commun 2010;46: 7090e108.

[5] Kurotobi K, Toude Y, Kawamoto K, Fujimori Y, Ito S, Chabera P, et al. Chem e A Eur J 2013;19:17075e81.
[6] Mozer AJ, Griffith MJ, Tsekouras G, Wagner P, Wallace GG, Mori S, et al. J Am Chem Soc 2009; $131: 15621 \mathrm{e} 3$.

[7] Chang Y-C, Wang C-L, Pan T-Y, Hong S-H, Lan C-M, Kuo H-H, et al. Chem Commun 2011;47:8910e2.

[8] Higashino T, Imahori H. Dalton Trans 2015;44:448e63.

[9] Hayashi S, Matsubara Y, Eu S, Hayashi H, Umeyama T, Matano Y, et al. Chem Lett 2008;37:846e7.

[10] Aljarilla A, Clifford JN, Pelleja L, Moncho A, Arrechea S, de la Cruz P, et al. J Mater Chem A 2013;1:13640e7.

[11] Pelleja L, Kumar CV, Clifford JN, Palomares E. J Phys Chem C 2014;118: 16504e9.

[12] Cabau L, Vijay Kumar C, Moncho A, Clifford JN, Lopez N, Palomares E. Energy Environ Sci 2015;8:1368e75.

[13] Barea EM, Caballero R, Lopez-Arroyo L, Guerrero A, de la Cruz P, Langa F, et al. ChemPhysChem 2011;12:961e5.

[14] Pelado B, de la Cruz P, Gonzalez-Pedro V, Barea EM, Langa F. Tetrahedron Lett 2012;53:6665e9.

[15] Griffith MJ, Mozer AJ, Tsekouras G, Dong Y, Wagner P, Wagner K, et al. Appl Phys Lett 2011;98:163502.

[16] Armel V, Pringle JM, Forsyth M, MacFarlane DR, Officer DL, Wagner P. Chem Commun 2010;46:3146e8.

[17] Lee C-W, Lu H-P, Lan C-M, Huang Y-L, Liang Y-R, Yen W-N, et al. Chem A Eur J 2009; $15: 1403$ e12.

[18] Griffith MJ, Sunahara K, Wagner P, Wagner K, Wallace GG, Officer DL, et al. Chem Commun 2012;48:4145e62.

[19] Wu S-L, Lu H-P, Yu H-T, Chuang S-H, Chiu C-L, Lee C-W, et al. Energy Environ Sci 2010;3:949e55.

[20] Arteaga D, Cotta R, Ortiz A, Insuasty B, Martin N, Echegoyen L. Dyes Pigments 2015; 112:127e37.

[21] Ragoussi M-E, de la Torre G, Torres T. Eur J Org Chem 2013;2013:2832e40.

[22] Wagner RW, Johnson TE, Li F, Lindsey JS. J Org Chem 1995;60:5266e 73.

[23] Pelleja L, Dominguez R, Aljarilla A, Clifford JN, de la Cruz P, Langa F, et al. ChemElectroChem 2014;1:1126e9.

[24] Arrechea S, Molina-Ontoria A, Aljarilla A, de la Cruz P, Langa F, Echegoyen L. Dyes Pigments 2015;121:109e17.

[25] D'Andrade BW, Datta S, Forrest SR, Djurovich P, Polikarpov E, Thompson ME. Org Electron 2005;6:11e20.

[26] Zewdu T, Clifford JN, Hernandez JP, Palomares E. Energy Environ Sci 2011;4: 4633e8. 